\title{
Extending International Human Rights Obligations to Political Parties
}

\author{
Tim Wood $^{*}$
}

\begin{abstract}
Conventional wisdom holds states, international organisations and occasionally individuals to be subjects of international law, with debate ongoing whether corporations and rebel groups can be said to have international human rights obligations. Political parties have not figured in this debate, yet of all non-state actors they are arguably the most natural bearers of international obligations. When in power, they span the very divide between public and private spheres which has historically determined the scope of application of human rights law. Even in opposition, political parties have the capacity to foster or thwart individuals' participation in governance and, with it, their dignity and human rights. Reflecting this centrality to democracy, they are directly addressed by diverse international instruments and bodies, a trend to be embraced and encouraged from prosecution authorities to election observer organisations.
\end{abstract}

\section{Keywords}

Non-state actors, human rights obligations, international law, political parties

\section{Introduction}

South African prosecutors made headlines when they recently announced their intention to commence an investigation into mass rapes committed during Zimbabwe's 2008 election campaign. Worldwide coverage hailed the first instance of an African state invoking universal jurisdiction to investigate crimes against humanity committed abroad by foreigners. Overlooked was another

Member of the New York Bar; Candidate, Master of International Law, Graduate Institute of International and Development Studies, Geneva; International Election Observer.

Copyright (c) the Author(s).

This work is licensed under a Creative Commons Attribution-NonCommercial-NoDerivs 3.0 License. 
first: the object of South Africa's investigation was neither Zimbabwean officials nor individual rapists, but Zimbabwe's ruling political party itself, ZANU-PF. ${ }^{1}$ Conventional wisdom holds states, international organisations and occasionally individuals to be subjects of international law, with debate ongoing as to whether corporations and rebel groups can be said to have international human rights obligations. ${ }^{2}$ Political parties have not figured in this debate, yet of all non-state actors they are arguably the most natural bearers of international obligations. When in power, they span the very divide between public and private spheres which has historically determined the scope of application of human rights law. ${ }^{3}$ Even in opposition, political parties have the capacity to foster or thwart individuals' participation in governance and, with it, their dignity and human rights. ${ }^{4}$ Reflecting this centrality to democracy, they are directly addressed by diverse international instruments and bodies, a trend to be embraced and encouraged from prosecution authorities to election observer organisations.

\section{Political parties and electoral misconduct}

At the outset, the nature of political parties and of the misconduct in which they sometimes engage will be examined by comparison with analogous phenomena more familiar to international law: rebel groups and armed conflict, respectively. In the process, characteristics making it impractical to impose international obligations on rebel groups will be seen not to bear on political parties.

\footnotetext{
${ }^{1}$ See e.g. G York, 'In ground-breaking move, S. Africa steps in over alleged Zimbabwe mass rapes', The Globe and Mail, 25 February 2013, <http://www.theglobeandmail .com/news/world/in-ground-breaking-move-s-africa-steps-in-over-alleged-zimbabwe-massrapes/article9016480/> [accessed 15 July 2013].

2 J Klabbers, '(I Can't Get No) Recognition: Subjects Doctrine and the Emergence of Non-State Actors', in J Petman \& J Klabbers (eds), Nordic Cosmopolitanism: Essays in International Law for Martti Koskenniemi (2003) 351, 352; see also A Clapham, 'Extending International Criminal Law beyond the Individual to Corporations and Armed Opposition Groups' (2008) $6 \mathrm{~J}$ Int Criminal Justice 899.

3 See N Rodley, 'Can Armed Opposition Groups Violate Human Rights?', in K E Mahoney \& P Mahoney (eds), Human Rights in the Twenty-first Century: A Global Challenge (1993) 297, 299 for a view of human rights as 'rules applicable to the relations between governments and governed'; J Knox, 'Horizontal Human Rights Law' (2008) 102 AJIL 1, 20, for the view that a '[...] nominally nongovernmental actor may be acting so much like a government, or in such close complicity with it, that it should be treated according to the same standards that apply to governments'.

${ }^{4}$ See B Boutros-Ghali, An Agenda for Democratization, UN Doc DPI/1867, 20 December 1996, paras $5,22,27$.
} 
The distinction between rebel groups and political parties is admittedly nebulous in societies experiencing or emerging from insurrection or civil war. Hezbollah in Lebanon, the People's Liberation Movement in South Sudan and the Liberation Tigers in Sri Lanka exemplify the 'continuum' along which political parties and rebel groups may be arrayed. ${ }^{5}$ Admonishing the last group on behalf of the United Nations, Professor Philip Alston warned that the Tamil Tigers' conduct would be evaluated against international standards by virtue of the fact that they 'aspire to represent a people before the world'. ${ }^{6}$ While conceding the theoretical relevance of such an aspiration in holding non-state actors to international obligations, Rodley has argued that in fact many rebel groups 'aspire merely to impede government or draw attention to perceived injustice.? Undoubtedly the objectives of rebel groups vary, but they remain fundamentally military in nature. ${ }^{8}$ Even when engaged in political activities, these tend to be instruments of or pretexts for an essentially military purpose. ${ }^{9}$ Political parties, on the other hand, are by definition 'association[s] [...] one of the aims of which is to participate in the management of public affairs.' ${ }^{10}$ Unlike armed groups, ${ }^{11}$ political parties' core vocation will, in democratic systems, be legitimate, legal and inherently laudable. Accordingly, whether they aspire to form the government-and, in a sense, to represent their state before the world-as in the case of large parties, or merely to influence government, in the case of smaller ones, political parties will be comparatively sensitive to the reputational implications of violating international obligations. Rebel groups, meanwhile, are more or less indifferent. ${ }^{12}$

${ }^{5} \mathrm{~J}$ de Zeeuw, 'Understanding the Political Transformation of Rebel Movements', in J de Zeeuw (ed), From Soldiers to Politicians: Transforming Rebel Movements After Civil War (2008) 17, 18.

6 P Alston, Report of the Special Rapporteur on extrajudicial, summary or arbitrary executions, UN Doc E/CN.4/2006/53/Add.5, 27 March 2006, para 27. See also J S Pictet (ed), Les conventions de Genève du 12 août 1949: Commentaire II (1959) 34, noting that rebels' 'prétention même de représenter le pays, du moins pour partie, les lie', but confining this to rebels exercising 'une autorité effective' over territory.

7 Rodley, above n 3, 301.

${ }^{8}$ De Zeeuw, above n $5,7$.

9 De Zeeuw, above n 5, 17-18.

${ }^{10}$ European Commission for Democracy through Law (Venice Commission), Guidelines and Report on the Financing of Political Parties, CFL-INF (2001) 8, 23 March 2001; De Zeeuw, above n 5, 5. See also K Kumar, 'Reflections on International Political Party Assistance' (2005) 12 Democratization 505,505 ("The term "political party" is used in its most generic sense indicating a group of citizens that are organized to seek and exercise power in a political system').

${ }^{11}$ Clapham, above n 2, 920.

${ }^{12}$ Ibid. See also Rodley, above n 3, 318 ('Only rarely will [rebel groups] have reason to feel bound 
Most states today are at least nominally democratic. ${ }^{13}$ Political parties' legitimacy and legality is attested to by the registration formalities imposed on them across jurisdictions: from submitting lists of nominating citizens (in Georgia and Malawi) or nominated candidates (in Madagascar and Benin) to paying a fee (in Tajikistan and the US) and solemnly disavowing affiliation with insurgents (in Afghanistan). ${ }^{14}$ Having duly registered, unlike rebel groups, ${ }^{15}$ parties are capable of being dissolved or stripped of their status by authorities on ostensibly principled grounds such as encouragement of crime (as in Turkey and Bosnia and Herzegovina). ${ }^{16}$ Finally, political parties' finances tend to be regulated by authorities, which may hold them to account for assets. ${ }^{17}$ For their part, rebel groups do not generally have assets in their names. ${ }^{18}$

The question of political parties' international obligations will ordinarily arise in the context of elections in societies transitioning towards democracy. ${ }^{19}$ Though not the only means or measure of participative governance, elections are the most regularly contentious. Electoral misconduct ranges from non-violent acts (fraud such as vote-buying and ballot- or count-tampering) to outright violence (intimidation of opposing candidates or supporters through property damage, harassment, and physical harm possibly rising to international criminal levels). ${ }^{20}$ In so far as political parties can be said to have international obligations not to interfere with opponents' human rights, these are the likely forms their violations will take.

Even at its most violent, however, the objectives, timing, perpetrators and

by international standards').

${ }^{13}$ Venice Commission, above n 10, 2. See also ACE Electoral Knowledge Network, 'Registration requirements for parties (Chamber 1)', <http://aceproject.org/epic-en/CDTable?ques tion $=$ PC001\&view $=$ country\&set_language $=$ en $>$ [accessed 15 July 2013].

14 ACE Electoral Knowledge Network, above n 13.

${ }^{15}$ Clapham, above n 2, 924.

${ }^{16}$ European Commission for Democracy through Law (Venice Commission), Guidelines on Prohibition and Dissolution of Political Parties and Analogous Measures, CDL-INF(2001) 1, 10 January 2000, 17.

${ }^{17}$ Venice Commission, above n 10, 13-14.

${ }^{18}$ Clapham, above n 2, 920.

${ }^{19}$ Kumar, above n 10, 505-506. See also De Zeeuw, above n 5, 251: 'Lacking an impartial judiciary, an independent election commission, and a strong, professional army, these countries face a real risk that rebel movements will continue their armed struggles when confronted with disappointing electoral results'.

${ }^{20}$ United Communist Party of Turkey v Turkey, [1998] 26 EHRR 121, para 23 (Communist Party of Turkey). See also F Oduro, 'Preventing Electoral Violence: Lessons from Ghana', in D Bekoe (ed), Voting in Fear: Electoral Violence in Sub-Saharan Africa (2012) 209, 214. 
victims ${ }^{21}$ of electoral misconduct distinguish it from the armed conflict engaged in by rebel groups. Qualitatively, electoral violence remains a 'deviant form' of political participation rather than a rejection of or alternative to politics. ${ }^{22}$ It is the dark side of democracy, a by-product of what Stanford anthropologist Thomas Hansen calls democracy's tendency to 'foreground [...] a cause, a grievance ${ }^{23}$ with as much potential to divide as to reconcile. Elections being episodic by nature, electoral violence will be more akin to the internal disturbances and tensions, such as riots [and] isolated and sporadic acts' which fall short of armed conflict as defined in humanitarian law. ${ }^{24}$ Two examples illustrate the particularity of electoral violence: 'electoral lists were reported to have been used in 1983 when the Sri Lankan ruling party's supporters, traveling in state-owned buses, carried out attacks on the Tamil population'; ${ }^{25}$ and '[w] omen throughout Zimbabwe who are affiliated with the MDC were abducted, beaten, and gang raped by President Mugabe's ZANU-PF youth militia [...]. ${ }^{26}$

The diffuse nature of electoral violence begs the question of what conduct might be legally attributed to a political party. ${ }^{27}$ Even assuming an act of misconduct can be traced to party employees or registered members, let alone mere supporters or sympathisers, to what extent do the perpetrators act in a political capacity? Members of Africa's notorious partisan youth organisations might be driven less by party affiliation and more by youthful aggression or material rewards. ${ }^{28}$ Like ZANU-PF in Zimbabwe, another rebel group turned political party, Kenya's African National Union, has put members of its youth

\footnotetext{
${ }^{21}$ D Bekoe, 'Introduction: the Scope, Nature and Pattern of Electoral Violence in Sub-Saharan Africa', in D Bekoe (ed), Voting in Fear: Electoral Violence in Sub-Saharan Africa (2007) 1, 2.

${ }^{22}$ A Mehler, 'Political Parties and Violence in Africa: Systematic Reflections against Empirical Background', in M Basedau, G Erdmann \& A Mehler (eds), Votes, Money and Violence: Political Parties and Elections in Sub-Saharan Africa (2007) 194, 210. See also Y Khan, 'South Asia: From Colonial Categories to a Crisis of Faith?', in A Murphy (ed), The Blackwell Companion to Religion and Violence (2011) 367, 371, noting the view that 'violence in South Asia [is] part and parcel of political life and just another tool on the spectrum of political methods'.

${ }^{23}$ T Hansen, 'The Political Theology of Violence in Contemporary India' (2012) 2 South Asia Multidisciplinary Academic Journal, <http://samaj.revues.org/1872> [accessed 7 April 2013]. See also Khan, above n 22, 374, noting a 'form of theatrical politics where the crowd takes on well-known scripts and actions'.

${ }^{24}$ Rodley, above n 3, 313.

${ }^{25}$ Khan, above n 22, 369.

${ }^{26}$ AIDS-Free World, Electing to Rape: Sexual Terror in Mugabe's Zimbabwe (2009) 15.

${ }^{27}$ Mehler, above n 22, 200-201; see also Rodley, above n 3, 301.

${ }^{28}$ Mehler, above n 22, 204-205.
} 
wing on the party payroll in past election campaigns. ${ }^{29}$ And how to disentangle partisan from ethnic motives? So frequently are ethno-religious cleavages exploited to political ends that, in a book surveying this correlation, Human Rights Watch felt it necessary to specify that it 'does not condemn the formation or existence of [...] political parties based on religious or ethnic affiliation' per se. ${ }^{30}$

The attribution question cannot be answered in the abstract. However, it is suggested that liability should not require evidence that party leaders 'explicitly called' for misconduct. ${ }^{31}$ That standard would exclude situations like the one in Apartheid South Africa, where:

[...] self-defense units set up with the encouragement of the ANC [African National Congress] became undisciplined and preyed on the communities they were supposed to protect. Meanwhile, radical black groups opposed to the negotiations, such as [...] the armed wing of the PAC [Pan Africanist Congress], carried out attacks on whites $[\ldots]^{32}$

Rather, the common law notion of vicarious liability should be relied on to assess political parties' breach of international obligations. In proceedings against a corporation under the US Alien Tort Statute, Judge Posner of the Seventh Circuit approved of civil liability for international law violations 'directed, encouraged or condoned at the [...] defendant's decisionmaking level'. ${ }^{33}$ This standard might be satisfied with respect to a political party, at least constructively, where gang-rapes of opponents are perpetrated at party 'base camps' by men chanting partisan slogans and wearing party-issued t-shirts. ${ }^{34}$ Similarly, in connection with international criminal law, non-state actors' liability may be founded upon 'organizational complicity' in the commission of any offence. ${ }^{35}$

\footnotetext{
${ }^{29}$ AIDS-Free World, above n 26, 46; L Laakso, 'Insights into Electoral Violence in Africa', in M Basedau, G Erdmann \& A Mehler, Votes, Money and Violence: Political Parties and Elections in Sub-Saharan Africa (2007) 224, 231.

${ }^{30}$ Human Rights Watch, Slaughter Among Neighbors: The Political Origins of Communal Violence (1995) 66. See also 2 and 7, and Khan, above $\mathrm{n} 22,369$.

${ }^{31}$ Mehler, above n 22, 203.

${ }^{32}$ Human Rights Watch, above n 30, 66.

${ }^{33}$ Flomo v Firestone Natural Rubber Co. LLC, 643 F.3d 1013, 1021 (7th Cir, 2011).

${ }^{34}$ AIDS-Free World, above n 26, 15, 18.

${ }^{35}$ Clapham, above n 2, 914.
} 


\section{Rationale for imposing international obligations on political parties}

The above examples make clear that if internationally enshrined rights of participative governance are to be protected, as mandated by the International Covenant on Civil and Political Rights, they need protecting as much from non-state actors as from authorities, if not more so. ${ }^{36}$ Comprising the rights to vote and seek elected office, participation rights are an end in themselves, affirming individual dignity and equality. In the UN General Assembly's estimation they are equally a means to ensure 'enjoyment of a wide range of other human rights and fundamental freedoms. ${ }^{37}$ This foundational or prophylactic role of participation rights distinguishes them from other human rights sought to be protected by imposing international obligations on non-state actors. When international tribunals or treaty bodies articulate such obligations, they are sometimes criticised as having intruded on the prerogatives of (elected) national governments. ${ }^{38}$ But this criticism assumes that such governments reflect the will of the people, whereas that is not true of political parties which triumph through electoral misconduct.

As recognised by the UN Human Rights Committee, political parties play a 'significant role in the conduct of public affairs and the election process.' ${ }^{39}$ Similarly the European Court of Human Rights has stated, 'political parties are a form of association essential to the proper functioning of democracy. ${ }^{40}$ Though the Court articulated this rationale for granting standing to political parties as claimants under international law, surely it militates equally strongly

${ }^{36}$ Ibid, 902. See also Knox, above n 3, 18: 'the enjoyment of many human rights may be interfered with by private actors, not just by governments; private actions must therefore be addressed to protect human rights fully', and also 19: 'Private actors unquestionably have the power to harm one another in ways that impair human rights'.

${ }^{37}$ GA Res 43/157, 8 December 1988. See also Boutros-Ghali, above n 4, 22, noting 'the mutually reinforcing relationship between democracy, development and respect for human rights', and 27 , stating democracy is based on and aims to promote the dignity and worth of the individual human being and the fundamental equality of all peoples'.

${ }^{38}$ A Clapham, Human Rights Obligations of Non-State Actors (2006) 558: 'some of those most antagonistic to the judicial enforcement of human rights obligations against non-state actors were concerned with the anti-majoritarian aspects of such a development through the delegation of crucial decisions to judges'.

${ }^{39}$ UN Human Rights Committee, General Comment No 25: The Right to Participate in Public Affairs, Voting Rights and the Right of Equal Access to Public Service, UN Doc CCPR/C/21/Rev.1/Add.7, 12 July 1996, para 26.

${ }^{40}$ Communist Party of Turkey, para 25. 
for imposing international obligations upon them. Political parties bring to bear collective resources and organisational capacity which, if used to bad ends, may gravely violate others' participation rights and human rights more generally. ${ }^{41}$ By the same token, where they contest elections in conformity with international norms, political parties have a unique capacity to foster participative governance. ${ }^{42}$ Their significance in this respect is affirmed by the Inter-American Democratic Charter adopted by members of the Organization of American States. Among other provisions, the Charter declares that ' $[t]$ he strengthening of political parties and other political organizations is a priority for democracy. ${ }^{43}$

A capacity to either inhibit or foster participation rights is enhanced in the case of ruling parties, separated as they are by only a 'thin line' from the resources of the state. ${ }^{44}$ From Africa to the former Soviet Union, there is a rich tradition of governments deploying state agents to do the dirty, partisan work of intimidating opposition candidates and supporters. ${ }^{45}$ If 'complicity' between nominally non-state actors and states is a common justification for holding non-state actors to international standards, ruling parties are the ultimate embodiment of this rationale. ${ }^{46}$ They do not merely act with or 'like' a government: they substantially are the government. ${ }^{47}$ And even where they do not directly exploit this status to violate opponents' participation rights, elected officials and their appointees may turn a blind eye as partisan agents do so for them. ${ }^{48}$ In so far as the infringed participation rights are enshrined only domestically, impunity will result to the

${ }^{41}$ Knox, above n 3, 19: 'Some private actors, such as multinational corporations and religious institutions, are powerful in their own right, even if they do not command armies'. See also Clapham, above n 2, 919, by analogy with corporations, arguing that organisations, unlike individuals, 'could be found liable due to a failure in their systems'.

${ }^{42}$ Kumar, above $\mathrm{n} 10,512$, noting with respect to the proliferation of international democracy assistance programs targeting political parties, "ii]t is assumed that once senior party officials obtain advice they need, they will disseminate the necessary information and communicate it to their local offices'.

${ }^{43}$ Inter-American Democratic Charter, OAS, 11 September 2001, 40 ILM 1289, Art 5.

${ }^{44}$ AIDS-Free World, above n 26, 43.

${ }^{45}$ See e.g. V Bunce \& S Wolchik, Defeating Authoritarian Leaders in Postcommunist Countries (2011) 184, 196; AIDS-Free World, above n 26, 10, noting 'rape and torture perpetrated by ZANU-PF youth militia [alongside] agents of Zimbabwe's Central Intelligence Organization'.

${ }^{46}$ Knox, above n 3, 20.

${ }^{47}$ Cf Zimbabwe Human Rights NGO Forum v Zimbabwe (2006) AHRLR 128, paras 137-141 (ACHPR 2006), noting formalistically that the ZANU (PF) is a political party (the ruling party) in Zimbabwe and just like any other party in the country, distinct from the government [...] even though some of the members of the Zimbabwe government-cabinet ministers, also hold top ranking positions in the party'.

${ }^{48}$ Knox, above n 3, 20. 
extent that domestic institutions prove unable or unwilling to hold either state or party to account. ${ }^{49}$ In such cases, international human rights obligations offer the only means of piercing the governmental veil and holding culpable political parties to account. ${ }^{50}$

\section{International framework of participation rights}

It is one thing to assert that political parties should be subject to international obligations. In assessing the extent to which political parties are subject to international obligations, if only by implication, the Universal Declaration of Human Rights and the International Covenant on Civil and Political Rights appear at first glance to offer fertile ground. Both instruments articulate sweeping rights of participation, as in Article 21 of the Universal Declaration of Human Rights:

(1) Everyone has the right to take part in the government of his country, directly or through freely chosen representatives.

$[\ldots]$

(3) The will of the people shall be the basis of the authority of government; this will shall be expressed in periodic and genuine elections $[. . .]^{51}$

So broad is this wording that it suggests converse duty-holders might extend beyond electoral authorities to include political parties. But the more fundamental question is whether the Universal Declaration enshrines any legal rights or obligations at all. Its dismissal by Rodley as comprising language of mere 'fact or faith $^{52}$ is overstated: even in the domestic context, legal rules typically are formulated as 'general declarations' rather than specific 'directives' ${ }^{53}$ And semantic generality alone cannot have deprived the Universal Declaration of legal signifi-

\footnotetext{
${ }^{49}$ Ibid. See also AIDS-Free World, above $\mathrm{n} 26,33$ : 'the police refused to file reports implicating the ZANU-PF in such crimes'.

${ }^{50}$ Knox, above n 3, 20.

${ }^{51}$ GA Res 217(III), 10 December 1948, Art 21 (Universal Declaration).

${ }^{52}$ Rodley, above n 3, 306.

${ }^{53}$ S Smith, 'Duties, Liabilities and Damages' (2008) 125 Harv LR 1727, 1746.
} 
cance given how many of its provisions, albeit not Article 21, have subsequently crystallised into customary international law. ${ }^{54}$

Rather, what takes the Universal Declaration out of the realm of treaty law binding states, much less political parties, is its status as a resolution of the UN General Assembly, unsigned and unratified, and its preambular self-description as setting out not rules but 'standard[s] of achievement'. ${ }^{55}$ Thus it falls to Article 25 of the International Covenant on Civil and Political Rights (ICCPR), a treaty ratified by 167 states, ${ }^{56}$ to enshrine rights of participative governance under international law:

Every citizen shall have the right and the opportunity, without any of the distinctions mentioned in article 2 and without unreasonable restrictions:

(a) To take part in the conduct of public affairs, directly or through freely chosen representatives;

(b) To vote and to be elected at genuine periodic elections which shall be by universal and equal suffrage and shall be held by secret ballot, guaranteeing the free expression of the will of the electors; [... $]^{57}$

As with the Universal Declaration, it is not obvious that corresponding obligations attach to electoral authorities to the exclusion of political parties. By way of contrast, the equivalent provision of the European Convention on Human Rights specifies unambiguously that it is the state 'Contracting Parties' which 'undertake to hold free elections [...] under conditions which will ensure the free expression of the opinion of the people. ${ }^{58}$ Moreover, the ICCPR expressly recognizes private persons' 'responsibility to strive for the promotion and observance of the rights' set out therein. ${ }^{59}$ Yet the UN Human Rights Committee, the independent body tasked with monitoring ICCPR compliance, has authoritatively interpreted the

\footnotetext{
${ }^{54}$ Knox, above n 3, 3, calling the Universal Declaration 'the seminal document for human rights law'; European Commission \& NEEDS, Compendium of International Standards for Elections $\left(2^{\text {nd }}\right.$ ed, 2007) 26.

${ }^{55}$ Universal Declaration, Preamble.

${ }^{56} 16$ December 1966, 999 UNTS 171; ICCPR Status as at 15 July 2013.

${ }^{57}$ Ibid, Art 25.

${ }^{58}$ Protocol to the Convention for the Protection of Human Rights and Fundamental Freedoms, 20 March 1952, 213 UNTS 262, Art 3.

${ }^{59}$ ICCPR, Preamble.
} 
treaty as binding states alone. ${ }^{60}$ As a matter of international law, the committee has emphasised that it remains for "[s]tates [to] ensure that, in their internal management, political parties respect the applicable provisions of article 25 in order to enable citizens to exercise their rights thereunder. ${ }^{6}{ }^{6}$

In short, neither the Universal Declaration nor the ICCPR as interpreted can be said to impose international legal obligations directly on political parties. Under these instruments, political parties lack 'sufficient status' to violate the enshrined norms or rights of participative governance. ${ }^{62}$ At most, state parties to the ICCPR are exhorted to transpose its provisions into domestic law, and thus to bind political parties indirectly by way of treaty-implementing legislation.

\section{International instruments addressing political parties}

That something is amiss with this interpretation of the ICCPR becomes clear when compared to that of another universal treaty, the Convention on the Elimination of all Forms of Discrimination against Women (CEDAW). CEDAW binds even more states than does the ICCPR. ${ }^{63}$ Like ICCPR Article 25, it contains a provision enshrining participation rights, albeit from a gender-specific perspective, in Article 7:

States Parties shall take all appropriate measures to eliminate discrimination against women in the political and public life of the country and, in particular, shall ensure to women, on equal terms with men, the right:

(a) To vote in all elections and public referenda and to be eligible for election to all publicly elected bodies;

\footnotetext{
${ }^{60}$ UN Human Rights Committee, General Comment No 31: The Nature of the General Legal Obligation Imposed on States Parties to the Covenant, UN Doc CCPR/C/21/Rev.1/Add.13, 26 May 2004, para 8.

${ }^{61}$ General Comment No 25, above n 39, para 26. See also General Comment No 31, above n 60, para 8 ('the positive obligations on States Parties to ensure Covenant rights will only be fully discharged if individuals are protected by the State, not just against violations of Covenant rights by its agents, but also against acts committed by private persons or entities that would impair the enjoyment of Covenant rights [...]').

${ }^{62}$ Rodley, above n 3, 303-304 ('we cannot easily presume that international law has invested certain private individuals or groups with sufficient status to become themselves violators of that law').

${ }^{63} 187$ parties as at 15 July 2013 .
} 
(b) $[\ldots]$ to hold public office $[. . .]^{64}$

On its face, CEDAW's explicit direction to states alone invites as restrictive an application as that given to the ICCPR. Yet the UN Committee on the Elimination of Discrimination against Women, the treaty body responsible for monitoring CEDAW's implementation, has authoritatively interpreted Article 7 to impose international obligations directly on political parties within ratifying states:

Political parties must embrace the principles of equal opportunity and democracy and endeavour to balance the number of male and female candidates. ${ }^{65}$

[...] political parties also have a responsibility to ensure that women are included in party lists and nominated for election in areas where they have a likelihood of electoral success. ${ }^{66}$

And:

[...] political parties have an obligation to demonstrate their commitment to the principle of gender equality in their constitutions, in the application of those rules and in the composition of their memberships $[. . .]^{67}$

CEDAW's implementing body is on solid interpretive ground in so far as it is widely accepted that treaties may impose international obligations directly on domestic actors and not simply the state parties as such. ${ }^{68}$ This position in no way detracts from the established rule that treaties cannot impose obligations on third states or international organisations without their express consent. ${ }^{69}$

While CEDAW's direct application to political parties depends upon interpretation of its provisions, some regional treaties address political parties explicitly. This may reflect a deliberate calculation by the governments of state parties

\footnotetext{
${ }^{64}$ Convention on the Elimination of All Forms of Discrimination against Women, 18 December 1979, 1249 UNTS 13, Art 7.

${ }^{65} \mathrm{UN}$ Committee on the Elimination of Discrimination against Women, CEDAW General Recommendation No. 23: Political and Public Life, UN Doc A/52/38/Rev.1, 12 August 1997, para 22.

${ }^{66}$ Ibid, para 28.

${ }^{67}$ Ibid, para 34.

${ }^{68}$ T Meron, Human Rights in Internal Strife: Their International Protection (1987) 36.

${ }^{69}$ Vienna Convention on Law of Treaties between States and International Organizations or between International Organizations, 21 March 1986, 25 ILM 543, Art 35.
} 
that international standards should apply to opposition parties just as they do the party which, by virtue of being in government, may find itself associated or imputed with the wrongful conduct of electoral authorities. ${ }^{70}$ Whatever the motivation, post-communist countries comprising the Commonwealth of Independent States (CIS) have concluded a Convention on the Standards of Democratic Elections, Electoral Rights and Freedoms. Now in force, the Convention reaffirms both the Universal Declaration and the ICCPR and proceeds to direct that '[n]o candidate, no political party (coalition), no other public association or public organization shall use the methods of psychic, physical, religious compulsion or calls for violence or threats of violence or any other forms of coercion, ${ }^{71}$ and that ' $[\mathrm{e}] \mathrm{ach}$ candidate and each political party (coalition) participating in elections shall accept the voting returns and results of democratic elections, ${ }^{72}$

Similarly, members of the Economic Community of West African States (ECOWAS) have signed a Protocol on Democracy and Good Governance which is in legal force ${ }^{73}$ The Protocol mandates that " $t$ ] he party and/or candidate who loses the elections shall concede defeat to the political party and/or candidate finally declared the winner [...]. ${ }^{74}$

Between these two instruments, 26 states from Turkmenistan to Togo have bound political parties to direct obligations under international law. The number and range of states embracing such norms is even more impressive when soft law instruments are factored in: that is, authoritative instruments not strictly binding in international law. For example, heads of government of the (then) 54 African Union member states have adopted a Declaration on the Principles Governing Democratic Elections. Like the CIS Convention, the AU Declaration reaffirms relevant provisions of the Universal Declaration and ICCPR in its preamble. It proceeds to direct that:

No individual or political party shall engage in any act that may

\footnotetext{
${ }^{70}$ Rodley, above n 3, 316, noting as regards state parties to the Geneva Conventions that "They would have had to be profoundly neglectful of their own interests blindly to allow the standards to be framed as applying to their own behaviour and not to that of their opponents'.

${ }^{71}$ Convention on the Standards of Democratic Elections, Electoral Rights and Freedoms in the Member States of the Commonwealth of Independent States, Commonwealth of Independent States, 7 October 2002, Art 8(3) (CIS Convention).

${ }_{72}^{72}$ Ibid, Art 9(7).

${ }^{73}$ M Diallo, 'Le protocole additionnel de 2001 de la CEDEAO : place et rôle dans la promotion de la démocratie et la gouvernance en Afrique de l'Ouest', 16-19 October 2007, 3 $<$ http://www.oecd.org/fr/csao/evenements/41506905.pdf> [accessed 15 July 2013].

${ }^{74}$ Protocol on Democracy and Good Governance, Economic Community of West African States, 21 December 2001, A/SP1/12/01, Art 9 (ECOWAS Protocol).
} 
lead to violence or deprive others of their constitutional rights and freedoms. ${ }^{75}$

Every candidate and political party shall respect the impartiality of the public media $[. . .]^{76}$

Every individual and political party participating in elections shall recognize the authority of the Electoral Commission or any statutory body empowered to oversee the electoral process and accordingly render full cooperation $[. . .]^{77}$

And:

Every citizen and political party shall accept the results of elections proclaimed to have been free and fair by the competent national bodies $[\ldots]$ or, challenge the result appropriately $[\ldots]^{78}$

The CIS Convention, ECOWAS Protocol and AU Declaration reflect the collective will of states' executives to impose international obligations on political parties within discrete regional blocs. In contrast, the Inter-Parliamentary Union (IPU) is an intergovernmental organisation consisting of states' legislative branches. Its reach is global, with 162 national member legislatures, and its influence is reflected in permanent UN observer status. The IPU's unanimouslyadopted Declaration on Criteria for Free and Fair Elections therefore evidences the breadth of support for international norms of political party conduct across not only territories but branches of government. Having reaffirmed the Universal Declaration and ICCPR in its preamble, the IPU Declaration states in relevant part that ' $[c]$ andidature, party and campaign rights carry responsibilities to the community. In particular, no candidate or political party shall engage in violence,; '[e]very candidate and political party competing in an election shall respect the rights and freedoms of others'; ${ }^{80}$ and that '[e]very candidate and po-

\footnotetext{
${ }^{75}$ Declaration on the Principles Governing Democratic Elections in Africa, African Union, 8 July 2002, AHG/Decl.1, Art. IV(8) (AU Declaration).

${ }^{76}$ Ibid, Art IV(11).

${ }^{77}$ Ibid, Art IV(12).

${ }^{78}$ Ibid, Art IV(13).

${ }^{79}$ Declaration on Criteria for Free and Fair Elections, Inter-Parliamentary Union, 26 March 1994, Art 3(9) (IPU Declaration).

${ }^{80}$ Ibid, Art 3(10).
} 
litical party competing in an election shall accept the outcome of a free and fair election.' 81

Whether hard or soft, strictly legal or merely political, the international instruments canvassed above permit a number of conclusions to be drawn as to the international legal status of political parties. First, as a matter of treaty law, the UN Human Rights Committee's interpretation of ICCPR Article 25 is increasingly an outlier in so far as it does not recognise the direct application of obligations to political parties. Subsequent agreements between state parties to a treaty such as the ICCPR have an interpretive role to play as regards that treaty, at least as between those states, whether by establishing their own interpretation of it-as the CIS Convention arguably does in explicitly referencing the ICCPR-or as a relevant rule of international law applicable to them in its own right, as the ECOWAS Protocol is. ${ }^{82}$ Even strictly non-binding instruments, such as the AU and IPU Declarations, are increasingly relied on to give content to treaty standards. $^{83}$ Therefore, a credible interpretation of ICCPR Article 25 would impose international obligations directly on political parties.

Second, as a matter of customary international law, hard as well as soft law instruments concluded by intergovernmental organisations have 'tremendous importance' in ascertaining the opinio iuris of states necessary to elucidate binding rules on the international plane. ${ }^{84}$ The collective will manifested by CIS, ECOWAS, IPU and AU member states to bind political parties rebuts Rodley's traditional, statist presumption against international law vesting non-state actors with 'sufficient status to become themselves violators of that law' ${ }^{85}$ Whatever opposition states might historically have evinced to treating non-state actors as 'proper' international legal subjects ${ }^{86}$ has, at least with respect to political parties,

${ }^{81}$ Ibid, Art 3(11).

${ }^{82}$ Vienna Convention on the Law of Treaties, 22 May 1969, 1155 UNTS 331, Art 31(3).

${ }^{83}$ A Bianchi, 'Looking ahead: international law's main challenges', in D Armstrong (ed), Routledge Handbook of International Law (2009) 392, 399.

${ }^{84}$ A Pellet, 'Article 38', in A Zimmerman, C Tomuschat \& K Oellers-Frahm (eds), The Statute of the International Court of Justice: A Commentary (2006) 677, 751-2. See also Bianchi, above n 83, 399 ('soft law may [...] set the preparatory stage for the development of international hard law'); G Abi-Saab, 'Éloge du droit assourdi: Quelques réflexions sur le rôle de la soft law en droit international contemporain', in Nouveaux itinéraires en droit : Hommage à Francois Rigaux (1993) 59, 66 ('le soft law d'aujourd'hui est ou énonce le hard law de demain').

${ }^{85}$ Rodley, above n 3, 304.

${ }^{86} \mathrm{Ibid}, 311$. See also Knox, above n 3, 19 ('A common belief used to be that international law cannot place such duties on private actors because, unlike governments, they are not subjects of international law, and only subjects of international law can hold rights and duties under it. If this conception of international law was ever valid, it is not now.'). 
collapsed spectacularly. That it has done so in similar terms across states from Africa to the former Soviet Union, many of them specially affected by electoral misconduct, adds credence to the possibility that we are witnessing the formation of customary international law binding upon political parties, at any rate on a regional basis. ${ }^{87}$ Moreover, the range of states concerned shows that this development is far from an exercise in cultural imperialism. ${ }^{88}$

Third, as a practical matter, it may be irrelevant to their importance whether the instruments surveyed above contribute to forming hard law. Treaties and custom deriving from state practice are increasingly viewed as outdated parameters of international law, confining it to a vertical, constraining role over states rather than a horizontal, facilitative role across societies. ${ }^{89}$ As Professor Hart has written in specific connection with international law, 'the proof that "binding" rules in any society exist, is simply that they are thought of, spoken of, and function as such' among relevant actors. ${ }^{90}$ Though not legally binding per se, the AU and IPU Declarations unambiguously 'formulate expectations' on political parties. ${ }^{91}$ This is clear from their consistent use of manifestly obligatory forms ('shall') rather than hortatory ones ('should'). ${ }^{92}$ If international law is well acquainted with 'hard' instruments containing 'soft' norms-that is, norms within treaties worded so conditionally as to be unenforceable ${ }^{93}$ - the unqualified wording of the AU and IPU Declarations effectively inverts that phenomenon. These are hard norms articulated in soft instruments.

On the ground, relevant actors are gradually taking note. Though still overwhelmingly focused on authorities' administration of elections, ${ }^{94}$ international election observer organisations will from time to time direct their only tool as

\footnotetext{
${ }^{87}$ Pellet, above $n$ 84, 752.

${ }^{88}$ Cf Rodley, above n 3, 317-318.

${ }^{89}$ Abi-Saab, above n 84, 60. See also Bianchi, above n 83, 398-9 ('although some norms are non-legally binding, they are [...] as effective in addressing the needs of the international community as legally binding norms').

${ }^{90}$ H L Hart, The Concept of Law (1 $1^{\text {st }}$ edn, 1961) 226.

${ }^{91}$ M Bothe, 'Legal and Non-Legal Norms-A Meaningful Distinction in International Relations?' (1980) 11 Netherlands YBIL 65, 68. See also Bianchi, above n 83, 404 ('to dismiss as "non-law" social practices that constitute the fabric of day-to-day international life and are increasingly perceived by the relevant actors as demanding respect as a matter of law [...] is unlikely to advance the cause of international law [...]').

${ }^{92}$ Cf Rodley, above n 3, 306.

${ }^{93}$ Bianchi, above n 83, 398.

${ }^{94}$ See e.g. A Davis-Roberts \& D J Carroll, 'Democracy Program, Using International Law to Assess Elections' (2010) The Carter Center, 3 ('much of the election observation community looks at the electoral process from the perspective of election administration').
} 
neutral third parties, their hortatory language, at political parties. The Office of Democratic Institutions and Human Rights of the Organization for Security and Cooperation in Europe (OSCE) is among the most established, undertaking election observations in the OSCE's 57 member states at the invitation of the state concerned. Following each observed election, the OSCE issues a report addressing various actors in the electoral process. Among other recommendations, recent reports have stated:

[...] political parties should take steps to ensure that no pressure is applied on public-sector employees or other citizens to attend campaign events, to desist from political activities, or to vote in a particular way. ${ }^{95}$

Parties should demonstrate the political will for the conduct of democratic elections commensurate with the broad privileges they enjoy under the law in regard to the conduct of elections. They should discharge their electoral duties in a responsible manner $[\ldots] .^{96}$

Even in the rare OSCE reports where they appear, however, recommendations directed at political parties are outnumbered by those directed at electoral authorities by a factor of some 25 to one. This may be due to the minimal role traditionally played by public international law in election observation frameworks. ${ }^{97}$ Given the developments canvassed above, it is suggested that these frameworks be revised to reflect the international obligations and norms which increasingly apply to political parties as well as electoral authorities. This is consistent with electoral observers' essentially passive function, to 'acknowledge the situation as a whole' while avoiding any apparent bias as between governing and opposition parties. ${ }^{98}$ But it also embraces their proactive potential as

${ }_{95}$ OSCE/ODIHR, Election Observation Mission Final Report: Ukraine Parliamentary Elections (2003), 17. See also OSCE/ODIHR, Election Observation Mission Final Report: Albania Parliamentary Elections (2009), 30.

${ }^{96}$ OSCE/ODIHR, Election Observation Mission Final Report: Albania Parliamentary Elections (2009), 28.

${ }^{97}$ Davis-Roberts \& Carroll, above n 94, 3.

${ }^{98}$ See section 3 above, for the suggestion that misconduct by electoral authorities may rightly or wrongly be imputed to governing parties, so that a focus exclusively upon such misconduct might lead the governing party to perceive bias against it. See Rodley, above n 3, 318, by analogy with humanitarian reporting: 'it is not in keeping with that ethos to fail to acknowledge the situation as a whole [...] Reporting of this nature, albeit refraining from categorizing such abuses or atrocities 
non-state actors to influence international standards and entrench emerging norms. ${ }^{99}$

\section{The European Court of Human Rights-and correlative obligations}

So far this paper has examined international instruments with an eye to isolating obligations directed at political parties. There is no question that all of the surveyed instruments recognise and enshrine rights of political parties under international law: not only participation rights as such, but 'adjacent' rights of expression, assembly and association. ${ }^{100}$ For example, the CIS Convention provides, 'political parties [...] shall be guaranteed freedom of campaigning carried out in all forms allowed by law.'101 And the ECOWAS Protocol states, 'political parties shall [...] have the right to carry out their activities freely, within the limits of the law. ${ }^{102}$ For political parties in the 47 Council of Europe member states, including such politically charged places as Azerbaijan, Bulgaria and Croatia, rights are accorded by the European Convention of Human Rights, and the European Court of Human Rights provides a concrete means of asserting those rights in the face of recalcitrant authorities. Throughout its history, the Strasbourg Court has granted political parties standing to bring claims before it. $^{103}$

If political parties may so clearly be endowed with international legal rights there can hardly be a substantive impediment inhering in international law to their being subjects for purposes of obligations. On the contrary, the question appears to be a procedural or practical one of whether to exercise

as human rights violations, would make it much harder for governments to legitimately reproach human rights reporters with moral selectiveness'.

${ }^{99}$ A Peters, L Koechlin \& G Zinkernagel, 'Non-state actors as standard setters: framing the issue in an interdisciplinary fashion', in A Peters, L Koechlin, T Förster \& G Zinkernagel (eds), Non-State Actors as Standard Setters (2009) 1. See also Clapham, above n 2, 921 (noting human rights observers' 'naming and shaming' function as to rebel groups).

${ }^{100}$ Standards for Elections, above n 54, 6 ('the adjective genuine can be seen to bring in the so-called adjacent political freedoms and rights, such as the freedom of expression, assembly, association, and movement').

${ }^{101}$ CIS Convention, Art 13(4).

${ }^{102}$ ECOWAS Protocol, Art 1(i). See also AU Declaration, Art. IV(6); IPU Declaration, Art 3(4).

${ }^{103}$ See e.g. Communist Party of Turkey, para 25; Republican Party of Russia v Russia, 12 April 2011, ECtHR App No 12976/07; Partidul Comunistilor (Nepeceristi) v Romania, 3 February 2005, ECtHR, App No 46626/99; Communist Party v Germany, 20 July 1957, ECtHR, App No 250/57. 
prescriptive or adjudicative jurisdiction over political parties. ${ }^{104}$ In this vein, a memorandum of the French Foreign Ministry addressing France's international criminal jurisdiction states:

France has long acknowledged [...] both the criminal liability of legal entities and the extraterritoriality of certain laws that apply to them in this regard. Legal entities include private law legal entities, both for-profit (companies, partnerships) and non-profit (associations, political parties [...] etc) ${ }^{105}$

The memorandum proceeds to explain that this jurisdiction is exercised sparingly on account of 'pressure from political parties and associations who feared that they might otherwise incur liability. ${ }^{106}$ In other words, political parties themselves recognise that nothing but the solicitude of states insulates them from international obligations.

While it lacks the prescriptive jurisdiction of the French state, the treatybased European Court of Human Rights has ingeniously wielded adjudicative jurisdiction to impose international obligations on political parties in select cases. It does so by invoking the abuse of rights doctrine, as codified in the Convention, ${ }^{107}$ to dismiss actions by political parties that either call for or have themselves 'resorted to illegal or undemocratic methods, encouraged the use of violence, aimed to undermine [the respondent state's] democratic and pluralist political system or pursued objectives that were racist or likely to destroy the rights and freedoms of others.' ${ }^{108}$ In this way, political parties within Council of Europe states can be seen to be subject to an 'obligation not to exceed certain limits in exercising' their participation rights 'and not to exercise [them] with the sole intention of harming others. ${ }^{109}$ While this obligation might leave something to be desired in so

${ }^{104} \mathrm{~J}$ L Brierly, 'The Basis of Obligation in International Law', in H Lauterpacht \& C Waldock (eds), The Basis of Obligation in International Law and Other Papers by the Late James Leslie Brierly (1958) 51; See also Knox, above n 3, 19 ('International law has the legal capacity to place direct horizontal duties on all private actors not to violate one another's human rights.').

${ }^{105}$ Human Rights Coordination Mission, Re: Criminal liability of private law legal entities under French law and extra-territoriality of the laws applicable to them: Review of the situation and discussion of issues (2006), quoted in Clapham, above n 2, 913-914.

${ }^{106}$ Ibid, 914.

${ }^{107}$ Convention for the Protection of Human Rights and Fundamental Freedoms, 4 November 1950, 213 UNTS 222, Art 17.

${ }^{108}$ Communist Party of Turkey, para 23.

${ }^{109} \mathrm{R}$ Ago, 'The Internationally Wrongful Act of the State, Source of International Responsibility: 3rd Report on State Responsibility', ILC Ybk 1971/II(1), 199, 222. 
far as its breach entails essentially procedural consequences for political parties appearing before the Court, nonetheless it advances the view that international obligations attach directly to political parties. Moreover, by formulating the obligation in essentially correlative terms as one of respect for the participation rights of fellow political parties and their supporters, the Court avoids a potential pitfall associated with the more diffuse converse obligations articulated in international instruments. Such obligations may be invoked strategically by governments, acting in a fundamentally partisan capacity, to 'offset' participation rights accorded by the state to opposition political parties. ${ }^{110}$

\section{Conclusion}

This paper has canvassed and sought to justify emerging international human rights obligations of political parties. Its focus has been on what might be termed primary obligations: that is, 'morally authoritative' obligations of general application rather than 'practically authoritative' obligations accruing to a specific actor upon breach of a primary obligation. ${ }^{111}$ Primary legal obligations exist independently of the secondary obligations (or lack thereof) through which they are enforced (or not). ${ }^{112}$ Thus, the International Court of Justice distinguishes the 'binding force' of obligations it imposes from the question of their enforceability, noting: 'the fact that the Court does not itself have the means to ensure the execution of orders [...] is not an argument against the binding nature of such orders. ${ }^{113}$ The emergence of primary obligations for political parties reflects a global consensus spanning actors as diverse as the UN Committee on the Elimination of Discrimination against Women, the Commonwealth of Independent States, France's Foreign Ministry and the Economic Community of

\footnotetext{
$\overline{{ }^{110} \text { Knox, above } \mathrm{n} 3,2 \text {. See also section } 3}$ above.

${ }^{111}$ Smith, above n 53, 1747, 1729 footnote 6 ('Primary legal duties arise from "not-wrongs", such as entering an agreement, being born, or attaining the age of majority. Secondary duties, by contrast, arise from legal wrongs, such as a breach of contract or a tort.'). See also J Combacau, 'Le droit international: bric-à-brac ou système' 31 Arch phil dr 85, 93 (describing a state in breach of international law as having traded 'son obligation substantiel primaire contre un obligation secondaire ayant un autre objet, l'obligation de réparer son manquement').

${ }^{112}$ Knox, above $\mathrm{n} 3,31$, noting that the duty not to commit genocide was directly imposed on individuals by the Genocide Convention long before an international tribunal was authorized to enforce that prohibition'.

${ }^{113}$ LaGrand (Germany v United States of America), ICJ Reports 2001 p 466, para 107. See also Knox, above $\mathrm{n} 3,30-31$, arguing, " $[\mathrm{t}]$ reaties that purport to place duties directly on private actors should be read as meaning what they say, just as any other treaties would be'.
} 
West African States. This paper has urged the UN Human Rights Committee and election observer organisations to advance this consensus by directly exhorting political parties, where appropriate, to respect their international obligations.

Other actors are already moving beyond primary international obligations when it comes to political parties. As has been seen, the European Court of $\mathrm{Hu}-$ man Rights will dismiss claims by political parties that have infringed the rights of others. South Africa's National Prosecution Authority has opened an investigation of ZANU-PF for crimes against humanity. These developments embody or set the stage for the particularised 'orders' (of reparation, of injunction, of forfeiture, etc.) that characterise secondary obligations. ${ }^{114}$ In time, whether through international criminal proceedings before domestic courts ${ }^{115}$ or decisions of independent treaty bodies, ${ }^{116}$ secondary obligations can be expected to extend to political parties.

\footnotetext{
${ }^{114}$ Smith, above $\mathrm{n} 53,1747,1750$. But cf The Diversion of Water from the Meuse (Netherlands v Belgium) (1937) PCIJ Ser A/B No 70, 79 (Judge Hudson, ind op): 'In international jurisprudence, however, sanctions are of a different nature and they play a different role, with the result that a declaratory judgment will frequently have the same compulsive force as a mandatory judgment'.

${ }^{115}$ Clapham, above n 2, 919. See also Knox, above n 3, 19 (acknowledging that international law could not possibly replicate the vast domestic resources devoted to regulating private invasions of interests denominated as human rights by international law [...]').

${ }^{116}$ Knox, above n 3,13 .
} 